dr inż. Marek Sobaś

Instytut Pojazdów Szynowych ,,TABOR”

\title{
Warunki wprowadzenia do eksploatacji używanych pojazdów szynowych trakcyjnych oraz tocznych
}

\begin{abstract}
$W$ artykule przedstawiono metodykę zagospodarowania osi staroużytecznych $w$ pojazdach szynowych trakcyjnych oraz tocznych. Przedstawiono sposób kwalifikacji osi zestawów kołowych z użyciem metod diagnostycznych. Artykuł zostat opracowany w ramach projektu badawczo-rozwojowego Nr R 10 004806/2009 pt. „Mikroprocesorowy system diagnostyczny głównych systemów trakcyjnego pojazdu szynowego uwzględniajacy ocenę bieżaca i prognozowanie stanów", finansowanego z budżetu Ministerstwa Nauki i Szkolnictwa Wyższego.
\end{abstract}

\section{WSTĘP}

Istotnym problemem w kolejnictwie jest zagospodarowanie osi zestawów kołowych, które najczęściej posiadają bardzo zaawansowany wiek. Taki przypadek występuje wtedy, gdy pojazd z różnych powodów jest złomowany, ale np. właściciel dokonuje selekcji części, które ze względu na swój stan techniczny nadają się do dalszej eksploatacji. Najczęstszym powodem złomowania jest wiek pojazdu i związany z nim stan techniczny, który nie kwalifikuje go jako całości do dalszej eksploatacji. Osie tak wyselekcjonowane określa się mianem osi „staroużytecznych". Zagospodarowanie tych osi w sposób racjonalny przyczynia się niewątpliwie do zwiększenia konkurencyjności taboru szynowego. W przypadku niektórych pojazdów, zwłaszcza wagonów towarowych koszty zestawów kołowych (w tym osi) stanowią istotny udział w całkowitym koszcie produkcji. Rozstrzygającym zagadnieniem, dającym podstawę do zagospodarowani osi staroużytecznych jest $\mathrm{w}$ tym przypadku uznanie poglądu, że podstawą do kwalifikacji do dalszej eksploatacji jest stan techniczny osi, a nie jej wiek. Takie sformułowanie problemu jest dużo bardziej uzasadnione z punktu widzenia technicznego oraz ekonomicznego. Stan techniczny osi zależy w dużym stopniu od producenta oraz użytkownika pojazdu, który w takim przypadku jest bardziej zainteresowany utrzymaniem osi zestawu kołowego po to, aby można było ją bezpiecznie użytkować jak najdłużej. Metodyka kwalifikacji osi zestawów kołowych powinna w sposób maksymalny zapewnić bezpieczeństwo eksploatacyjne. Należy również zauważyć, że zwiększył się zasób wiedzy w naszym kraju oraz w Europie na temat warunków wykonania i odbioru, wytrzymałości zmęczeniowej oraz warunków eksploatacyjnych. Problematyka ograniczenia wieku użytkowania zestawów kołowych wiąże się z planowaną żywotnością układów biegowych, który jest istotną częścią pojazdów szynowych. Taki sposób podejścia jest przedstawiony w ORE/ERRI B12/Rp.14/D [26], gdzie oszacowany wiek standaryzowanych układów biegowych wynosi 40 lat. Tak więc w zamyśle autorów raportu takie części wysoko obciążone jak ramy (przeważnie konstrukcje spawane), elementy zawieszenia jak sprężyny śrubowe i resory oraz osie powinny wykazywać taką minimalną żywotność. Wykonawstwo tych części w istotny sposób rzutuje na koszty wykonania całego układu biegowego. Warto dodać, że istotnym argumentem świadczącym za zagospodarowaniem osi staroużytecznych jest fakt, że metodyka obliczeń wytrzymałości statycznej oraz zmęczeniowej osi zestawów kołowych wg PN-EN 13103:2009 (osie pojazdów tocznych) [8] oraz wg PN-EN 13104:2009 (osie pojazdów trakcyjnych) [9] nie określa granicznej żywotności osi. Metodyka obliczeń ta jest oparta na wcześniej stosowanych przepisach ORE/ERRI np. w raporcie ORE/ERRI B136/Rp.11/D [27] oraz w karcie UIC 515-3 [22]. Jak pokazały badania doświadczalne przeprowadzone na próbkach osi zestawów kołowych w skali 1:1 granica zmęczenia na obustronne zginanie $\mathrm{Z}_{\mathrm{go}}$ została ustalona na poziomie $200 \mathrm{MPa}$, a wiec identycznym jak przewiduje norma PN-EN 13261+A1:2011[11] dla stali EA1N. Próbki te były wykonane ze stali St5P wg PN-64/H-84027 [16]. Poprawność przeprowadzonych badań stanowiskowych potwierdziła eksploatacja komercyjna. Artykuł jest kontynuacją prac studialnych, poświęconej problema-

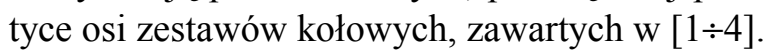

\section{METODYKA KWALIFIKACJI \\ 2.1. DEFINICJA OSI STAROUŻYTECZNEJ}

Przez oś „staroużyteczną” rozumie się taką, która:

$\Rightarrow$ była już w sposób ciagły użytkowana w długoletniej eksploatacji komercyjnej w pojazdach trakcyjnych (lokomotywy, pojazdy trakcyjne, 
Zestawienie składu chemicznego gatunków stali wg PN-84/H-84027/03 [17] w porównaniu ze stalą EA1N wg PN-EN 13261+A1:2011 [11]

Tabela 1

\begin{tabular}{|l|c|c|c|c|c|c|c|c|c|c|}
\hline \multirow{2}{*}{$\begin{array}{l}\text { Gat. } \\
\text { stali }\end{array}$} & $\mathbf{C}$ & $\mathbf{S i}$ & $\mathbf{M n}$ & $\mathbf{P}$ & $\mathbf{S}$ & $\mathbf{C r}$ & $\mathbf{C u}$ & $\mathbf{M o}$ & $\mathbf{N i}$ & $\mathbf{V}$ \\
\hline & \multicolumn{8}{|c|}{ Zawartość procentowa pierwiastków } \\
\hline EA1N & 0,40 & 0,50 & 1,20 & 0,020 & 0,020 & 0,30 & 0,30 & 0,08 & 0,30 & 0,06 \\
\hline P35G & $0,30 \div 0,40$ & $0,15 \div 0,35$ & $0,80 \div 1,20$ & 0,040 & 0,040 & 0,30 & 0,30 & 0,05 & 0,30 & 0,05 \\
\hline P35 & $0,30 \div 0,40$ & $0,15 \div 0,35$ & $0,50 \div 1,00$ & 0,040 & 0,040 & $0,90 \div 1,20$ & 0,30 & 0,05 & 0,30 & 0,06 \\
\hline P40 & $0,37 \div 0,45$ & $0,15 \div 0,35$ & $0,60 \div 0,90$ & 0,040 & 0,040 & 0,30 & 0,30 & 0,05 & 0,30 & 0,05 \\
\hline
\end{tabular}

Zestawienie własności wytrzymałościowych gatunków stali wg PN-84/H-84027/03 [17] w porównaniu ze stalą EA1N wg PN-EN 13261+A1:2011[11]

Tabela 2

\begin{tabular}{|c|c|c|c|c|c|}
\hline \multirow{3}{*}{ Gatunek stali } & $\mathbf{R}_{\mathrm{eH}}$ & $\mathbf{R m}$ & $\mathbf{A}_{\mathbf{5}}$ & $\begin{array}{c}\text { KU w kierun- } \\
\text { ku wzdlużnym }\end{array}$ & $\begin{array}{c}\text { KU w kierun- } \\
\text { ku poprzecz- } \\
\text { nym }\end{array}$ \\
\cline { 2 - 6 } & {$[\boldsymbol{M P a}]$} & {$[\mathbf{M P a}]$} & {$[\boldsymbol{\%}]$} & {$[\boldsymbol{J}]$} & {$[\boldsymbol{J}]$} \\
\hline EA1N & $\geq 320$ & $550 \div 650$ & $\geq 22$ & $\geq 30$ & $\geq 20$ \\
\hline P35G & $\geq 300$ & $550 \div 650$ & $\geq 23$ & $\geq 60$ & $\geq 20$ \\
\hline P35 & $\geq 280$ & $500 \div 650$ & $\geq 21$ & $\geq 50$ & $\geq 20$ \\
\hline P40 & $\geq 300$ & min. 560 & $\geq 20$ & $\geq 50$ & - \\
\hline
\end{tabular}

pojazdy specjalne) lub tocznych (wagony osobowe, wagony towarowe)

$\Rightarrow$ jej przebieg eksploatacji jest „odtwarzalny”.

Podstawowym warunkiem kwalifikacji osi „staroużytecznej" do dalszej eksploatacji jest udokumentowanie jej pochodzenia i dotychczasowego przebiegu eksploatacyjnego.

Zainteresowany musi udowodnić:

$\Rightarrow$ pod jakimi pojazdami była ona eksploatowana

$\Rightarrow$ jej przebieg kilometrowy.

W przypadku wagonów towarowych nie jest to możliwe, w związku z czym należy podać pod jakim wagonem (wagonami) była eksploatowana. Należy się spodziewać, że osie „stroużyteczne” będą wykonane ze stali P35G, P35, natomiast w przypadków pojazdów trakcyjnych ze stali P40 wg PN-84/H-84027/03 [17] oraz wykonanych wcześniej ze stali A1N wg karty UIC 811-1 [23]. Skład chemiczny poszczególnych stali $\mathrm{w}$ porównaniu ze stalą EA1N wg PNEN13261+A1:2011 [11] jest przedstawiony w tabeli 1.

Własności wytrzymałościowe stali P35G, P35 oraz P40 w porównaniu ze stalą EA1N wg PN-EN13261 +A1:2011 [11] są przedstawione w tabeli 2 .

Stanowisko do badań zmęczeniowych było wykonane przez HCP Cegielski w Poznaniu wg dokumentacji konstrukcyjnej, opracowanej w IPS „Tabor”. Przedmiotem badań porównawczych były próbki rolowane (utwardzane powierzchniowo) oraz nie utwardzane powierzchniowo) osi zestawów kołowych, standardowych typu A wg karty UIC 510-1 [20] oraz normy PN-92/K-91048 [19] o wymiarach czopa $120 \times 179$ $\mathrm{mm}$. Wymiary poszczególnych stref osi są przedstawione na rys. 2 .
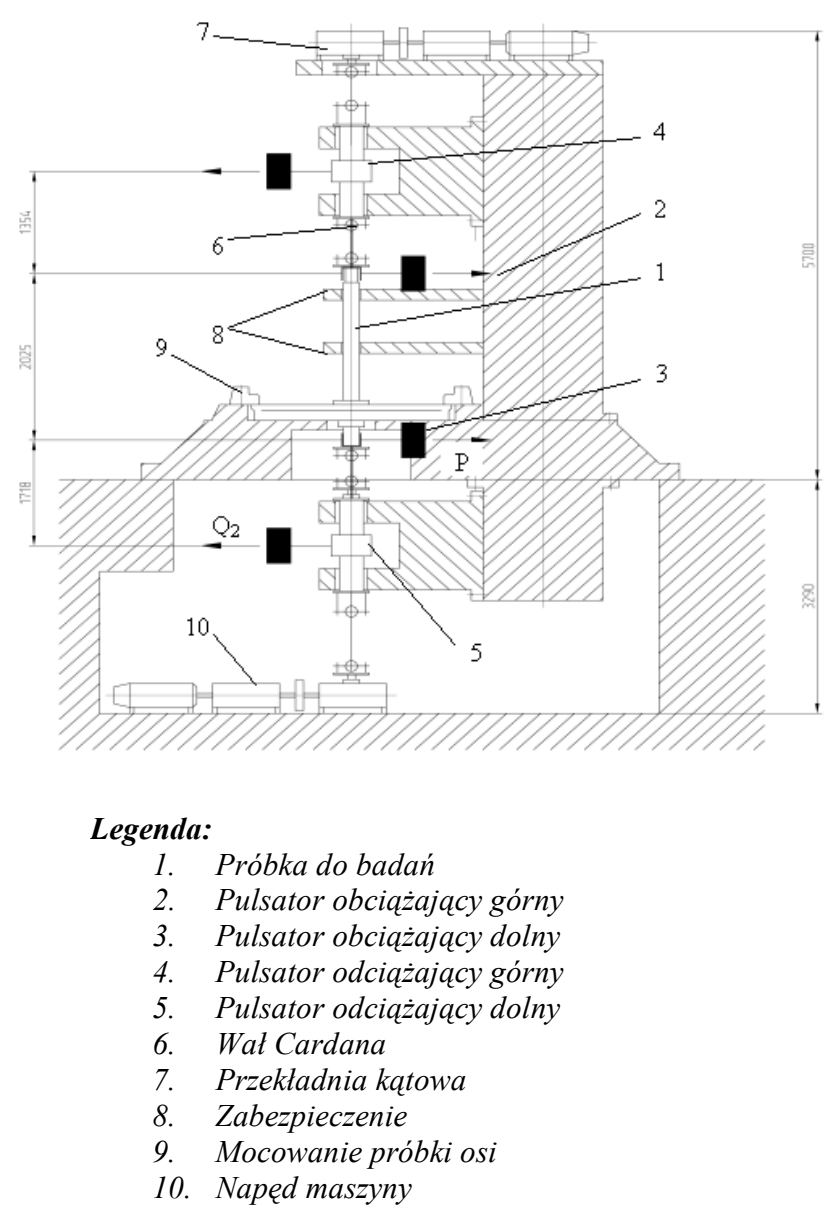

Rys.1. Schemat maszyny do badań zmęczeniowych osi zestawów kołowych wg [5] 


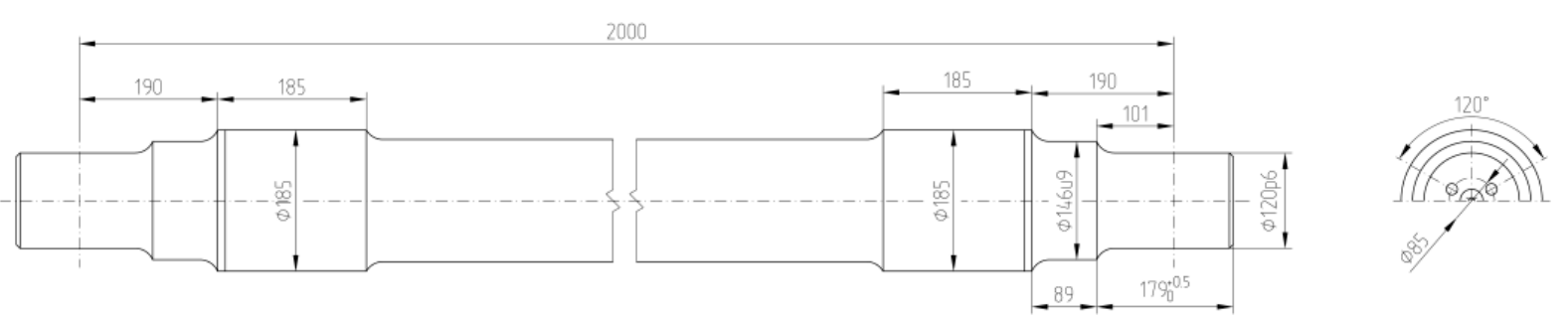

Rys.2. Oś zestawu kołowego typu A o wymiarach czopa $120 \times 179 \mathrm{~mm}$

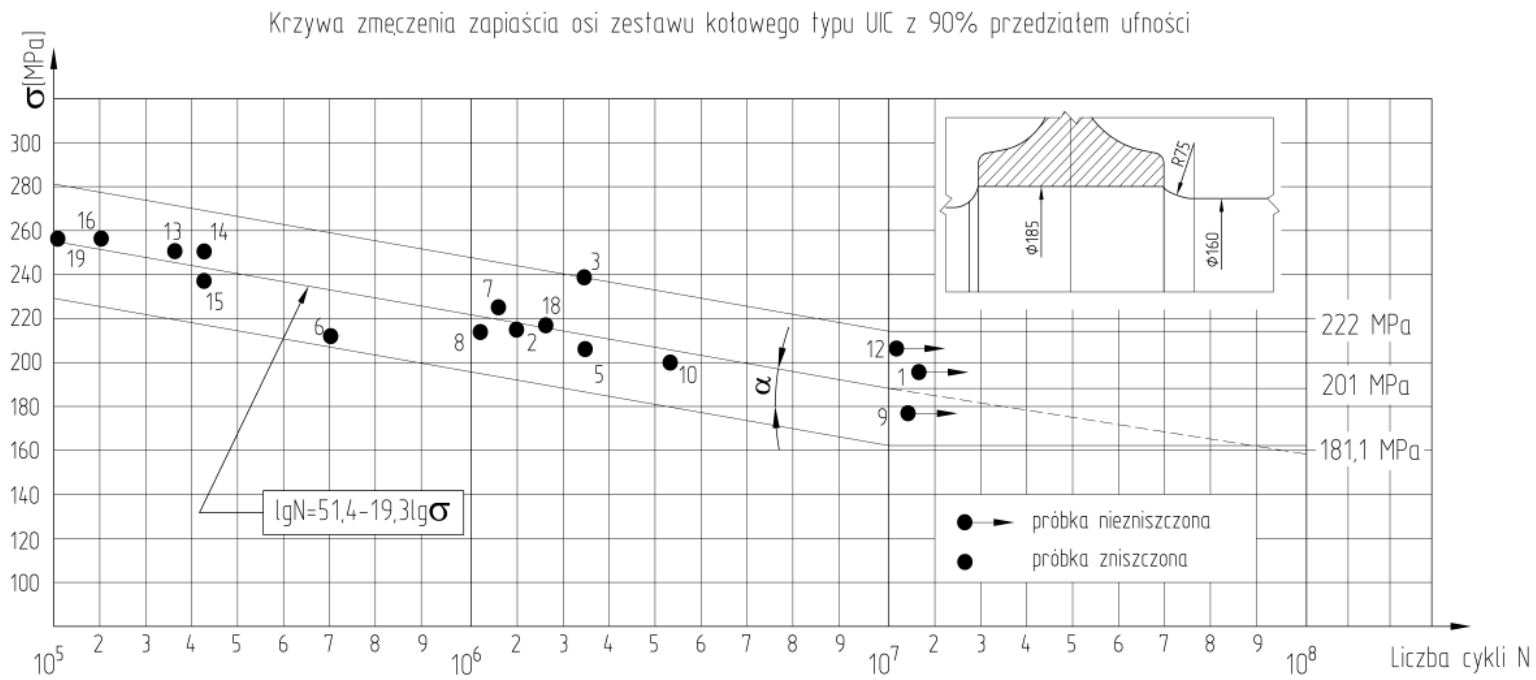

Rys.3. Krzywa zmęczenia „zapiaścia” osi zestawu kołowego typu UIC z 90\% przedziałem ufności wg [5]

Opis badań próbek osi w skali 1:1 oraz ich wyniki zostały szczegółowo przedstawione $\mathrm{w}$ opracowaniu [2]. Przedmiotem badań była strefa „zapiaścia” osi, tzn. strefy za osadzeniem koła. W przypadku próbek nie poddanych procesowi rolowania powierzchniowego osiagnięto tą samą granicę zmęczenia „zapiaścia" osi zestawu kołowego, która jest wymieniona w normie PN-EN 13261+A1:2011 [11] tzn. $200 \mathrm{MPa}$. Wyniki badań poszczególnych próbek osi nie poddanych procesowi rolowania są przedstawione na rys.3. Wykonawcą wszystkich próbek osi był Huta 1-go Maja w Gliwicach. Podpiaście i ,zapaście” próbek osi rolowano (utwardzano powierzchniowo) przy następujących parametrach:

\section{$>$ nacisk na rolkę $26,5 \mathrm{kN}$ \\ $>$ średnica rolki $150 \mathrm{~mm}$ \\ $>$ promień rolki $15 \mathrm{~mm}$.}

Głębokość warstwy utwardzonej odpowiadająca tym parametrom rolowania wynosiła od $2,4 \div 4,8 \mathrm{~mm}$, co odpowiadało wzrostowi twardości od 24 do $48 \%$. Wszystkie próbki osi były wykonane ze stali St5P wg PN-64/H-84027 [16] i pochodziły z jednego wytopu. Jak pokazały badania próbek, średnia granica zmęczenia $Z_{\mathrm{go}}$ próbek z rolowanym „zapiaściem” osi wyniosła $245 \mathrm{MPa}$, co dało wzrost w stosunku do granicy zmęczenia dla osi nie poddanych procesowi rolowania, wynoszącej $200 \mathrm{MPa}$. Można więc wyciągnąć wniosek, że rolowanie powierzchniowe przyczyniające się do umocnienia powierzchniowego jest zabiegiem technologicznym, zwiększającym wytrzymałość zmęczeniową. Stal St5P wg PN-64/H84027 [16] odpowiada pod względem składu chemicznego i własności wytrzymałościowych stali P35 lub P35G. Porównanie składu chemicznego i własności wytrzymałościowych stali P35G, P35,P40 EA1N i St5P jest przedstawione odpowiednio $\mathrm{w}$ tabeli 3 i

Analizując tabelę 3 i 4, można wyciagnąć wniosek, że pozytywne wyniki rolowania powierzchni osi zestawów kołowych mogą odnosić się również do stali P35, P35G (również wykonanej wg normy PN-91/K84027/03 [18] oraz EA1N wg PN-EN 13261+A1:2011 [11]. Charakterystyczne jest również to, że stal St5P posiada dużo większą zawartość fosforu i siarki aniżeli pozostałe stale oraz nie zawiera pierwiastków stopowych takich jak np. chrom, miedź molibden, nikiel i wanad. W wyniku przeprowadzonych badań zmęczeniowych na stanowisku badawczym można stwierdzić, że rolowanie jednoznacznie zwiększa granicę zmęczenia na obustronne zginanie obrotowe osi zestawu kołowego.

\subsection{KWALIFIKACJA OSI \\ 2.2.1. ZNAKOWANIE}

Podstawą do zakwalifikowania osi „staroużytecznej" do dalszej eksploatacji jest znakowanie na osi, gdzie na powierzchniach czołowych powinny być wybite następujące znaki:

- numer kolejny osi danego wytopu

- znak gatunku stali (oznaczenie stali) i sposób obróbki cieplnej 
Zestawienie składu chemicznego gatunku stali St5P wg PN-64/H-84027 [16] w porównaniu z gatunkami stali wg PN84/H-84027/03 [17] stalą EA1N wg PN-EN 13261+A1:2011 [11]

Tabela 3

\begin{tabular}{|c|c|c|c|c|c|c|c|c|c|c|c|c|}
\hline \multirow{2}{*}{$\begin{array}{l}\text { Gat. } \\
\text { stali }\end{array}$} & $\mathbf{C}$ & $\mathbf{S i}$ & $\mathbf{M n}$ & $\mathbf{P}$ & $\mathbf{S}$ & \multicolumn{1}{c|}{$\mathbf{C r}$} & $\mathbf{C u}$ & $\mathbf{M o}$ & $\mathbf{N i}$ & $\mathbf{V}$ \\
\cline { 2 - 11 } & \multicolumn{9}{|c|}{ Zawartość procentowa pierwiastków [\%] } \\
\hline EA1N & 0,40 & 0,50 & 1,20 & 0,020 & 0,020 & 0,30 & 0,30 & 0,08 & 0,30 & 0,06 \\
\hline P35G & $0,30 \div 0,40$ & $0,15 \div 0,35$ & $0,80 \div 1,20$ & 0,040 & 0,040 & 0,30 & 0,30 & 0,05 & 0,30 & 0,05 \\
\hline P35 & $0,30 \div 0,40$ & $0,15 \div 0,35$ & $0,50 \div 1,00$ & 0,040 & 0,040 & $0,90 \div 1,20$ & 0,30 & 0,05 & 0,30 & 0,06 \\
\hline P40 & $0,37 \div 0,45$ & $0,15 \div 0,35$ & $0,60 \div 0,90$ & 0,040 & 0,040 & 0,30 & 0,30 & 0,05 & 0,30 & 0,05 \\
\hline St5P & $\begin{array}{c}\text { nie określa } \\
\text { się }\end{array}$ & max.0.50 & max 1,0 & 0,050 & 0,050 & - & - & - & - & - \\
\hline
\end{tabular}

Zestawienie wlasności wytrzymałościowych gatunku stali St5P wg PN-64/H-84027 [16] w porównaniu z gatunkami stali wg PN-84/H-84027/03 [17] stalą EA1N wg PN-EN 13261+A1:2011 [11]

Tabela 4

\begin{tabular}{|c|c|c|c|c|c|}
\hline \multirow{2}{*}{ Gatunek stali } & $\mathbf{R}_{\mathrm{eH}}$ & $\mathbf{R}_{\mathrm{m}}$ & $\mathbf{A}_{\mathbf{5}}$ & $\begin{array}{c}\text { KU w kierun- } \\
\text { ku wzdłużnym }\end{array}$ & $\begin{array}{c}\text { KU w kierun- } \\
\text { ku poprzecz- } \\
\text { nym }\end{array}$ \\
\cline { 2 - 6 } & {$[\mathbf{M P a}]$} & {$[\mathbf{M P a}]$} & {$[\%]$} & {$[\boldsymbol{J}]$} & $\geq 20$ \\
\hline EA1N & $\geq 320$ & $550 \div 650$ & $\geq 22$ & $\geq 30$ & $\geq 20$ \\
\hline P35G & $\geq 300$ & $550 \div 650$ & $\geq 23$ & $\geq 50$ & $\geq 20$ \\
\hline P35 & $\geq 280$ & $500 \div 650$ & $\geq 21$ & $\geq 50$ & - \\
\hline P40 & $\geq 300$ & $\min .560$ & $\geq 20$ & - & - \\
\hline
\end{tabular}

- miesiąc i rok wykonania (dwie ostanie cyfry roku)

- znak producenta (wytwórni)

- znak kontroli jakości producenta

- znak kontroli użytkownika (np. inspektora od-

biorczego PKP)

- inne znaki uzgodnione z zamawiającym.

Znaki powinny być wybite na zimno „stemplem” o krawędziach zaokraglonych na powierzchniach czołowych osi zestawu kołowego i powinny być czytelne. Brak widocznych znaków na powierzchni czołowej osi jest poważnym argumentem za przerwaniem procedury dopuszczenia osi zestawów kołowych do dalszej kwalifikacji do eksploatacji. Nie wiadomo bowiem z jakiej stali osi została wykonana.

\subsubsection{KONTROLA WIZUALNA}

Celem kontroli wizualnej VT jest sprawdzenie uszkodzeń osi okiem nieuzbrojonym.

Kryteria oceny wizualnej:

- niedopuszczalne jest występowanie wad widocznych gołym okiem tzn. w kierunku wzdłużnym, w kierunku obwodowym oraz w kierunku poprzecznym (odpowiednio rys.4, rys.5 oraz rys.6).
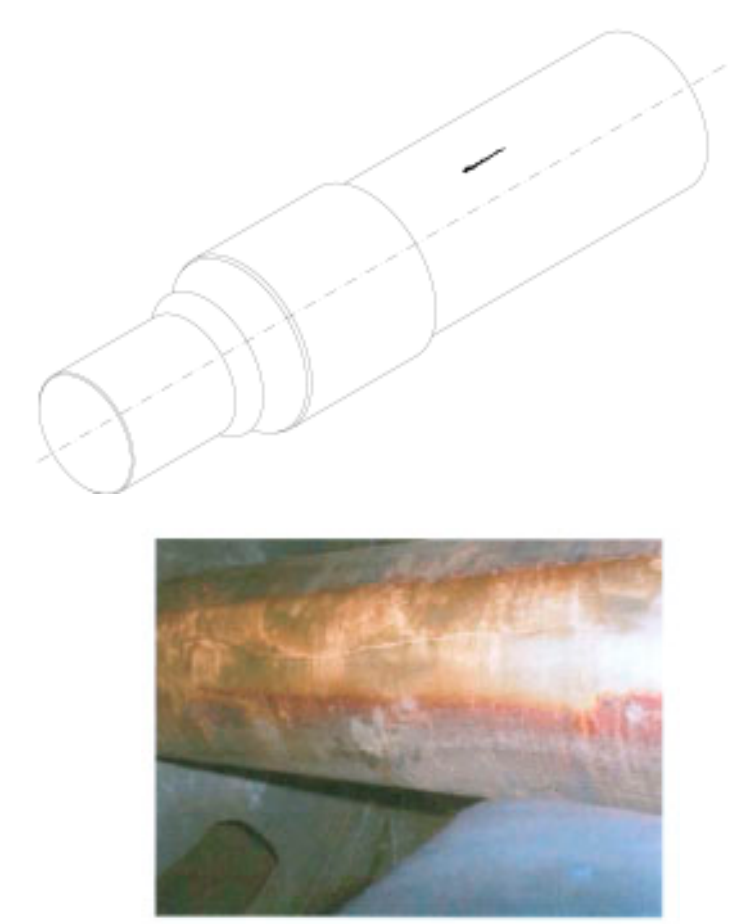

Rys.4. Wada osi w kierunku wzdłużnym wg PN-EN 15313 [15] 

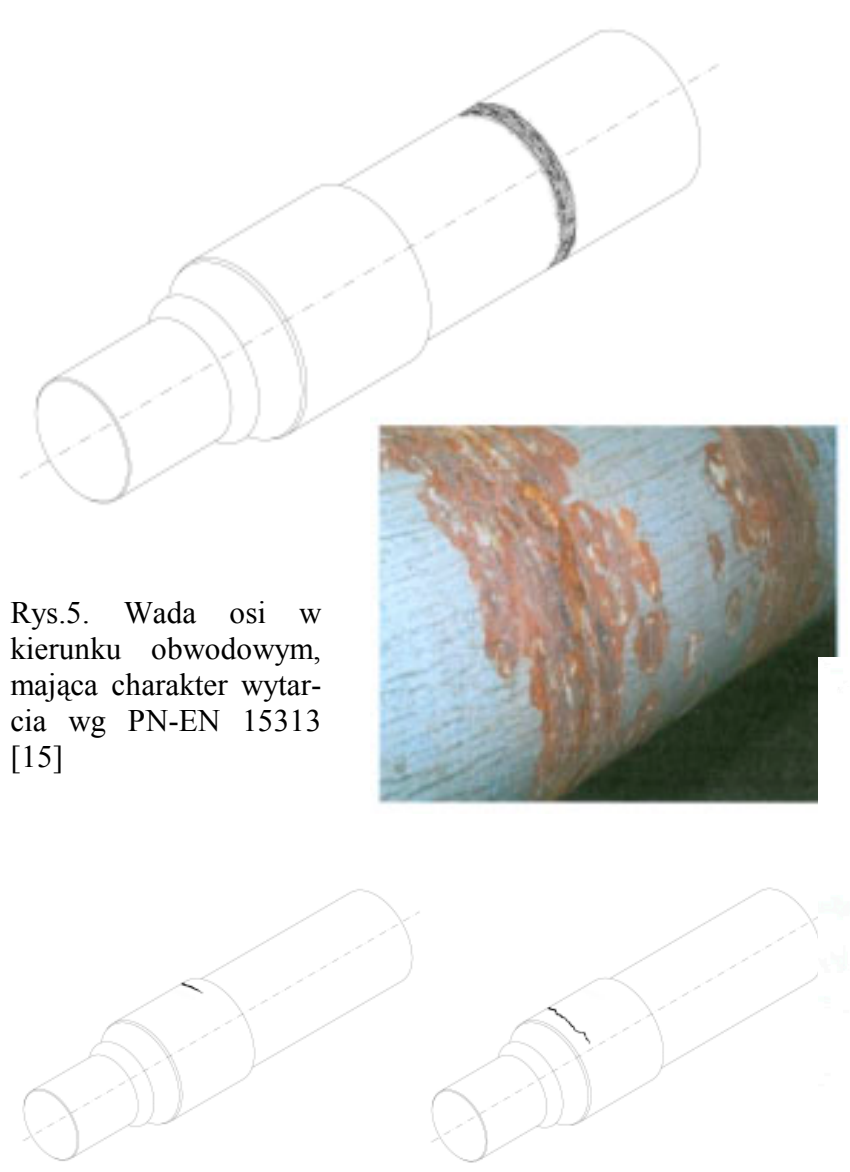

Rys.6. Wada osi w kierunku poprzecznym (pęknięcia na obwodzie) wg PN-EN 15313 [15]

- uszkodzeń na powierzchniach poszczególnych strefach osi powstałych w wyniku uderzeń mechanicznych; w przypadku ich stwierdzenia osi nie można dalej kwalifikować; uszkodzenia tego rodzaju mogą być źródłem uszkodzeń zmęczeniowych osi, propagującym szybko do wewnątrz materiału, a w konsekwencji powodującym pęknięcia i zagrażają bezpiecznej eksploatacji.

jakiegokolwiek znakowania na powierzchniach nośnych osi (czop osi, powierzchnie osadcze, przedpiaście, część środkowa osi, na promieniach przejściowych pomiędzy poszczególnymi powierzchniami nośnymi) za pomocą znaków wklęsłych.

\subsubsection{SPRAWDZENIE GEOMETRII OSI}

Oś należy kwalifikować w oparciu o dokumentację konstrukcyjną.

W oparciu o rysunek konstrukcyjny należy dokonać pomiarów:

$\Rightarrow$ podstawowych wymiarów długościowych, średnic: czopa, przedpiaść, podpiaść, części środkowych osi, promieni przejściowych pomiędzy poszczególnymi strefami osi

$\Rightarrow$ wymaganych parametrów chropowatości osi dla poszczególnych stref osi,

$\Rightarrow$ odchyłek kształtu i położenia,

$\Rightarrow$ sprawdzeniu wymiarów nakiełków osi oraz
$\Rightarrow$ sprawdzeniu stanu gwintów do mocowania pierścienia dociskowego.

Pomiary parametrów chropowatości należy przeprowadzić elektronicznym przyrządem do pomiaru chropowatości mierzącym wszystkie trzy parametry chropowatości $\mathrm{R}_{\mathrm{a}}, \mathrm{R}_{\mathrm{t}}$ oraz $\mathrm{R}_{\mathrm{z}}$; Zabrania się pomiarów chropowatości za pomocą wzorców chropowatości, ze względu na subiektywność w ocenie stanu powierzchni. Zwraca się uwagę na kontrolę parametru $\mathrm{R}_{\mathrm{t}}$, jako największą wysokość nierówności profilu, czyli odległość między dwiema liniami równoległymi do linii średniej, z których jedna przechodzi przez najwyższy punkt profilu (linia wierzchołków), a druga przez najniższy punkt (linia wgłębień). Parametr $\mathrm{R}_{\mathrm{t}}$ jest przedstawiony na rys.7.

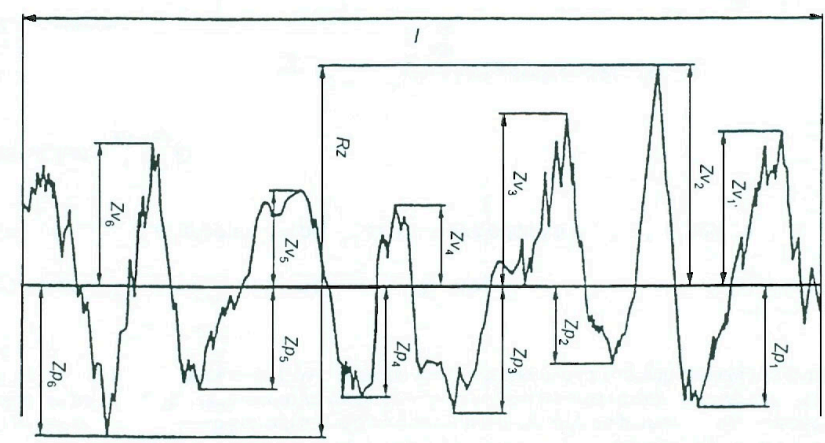

Legenda:

$R_{Z}\left(R_{t}\right)$

$Z_{v i}$ - linia wierzchołków

$Z_{p i}$ - linia wgłębień

$l$ - dlugość odcinka elementarnego

Rys.7. Definicja parametru $\mathrm{R}_{\mathrm{t}}$

Należy zwrócić uwagę na fakt, że parametr ten bardziej charakteryzuje wrażliwość powierzchni na działanie karbu. Przykład zależności wytrzymałości zmęczeniowej od parametru $R_{t}$ jest przedstawiony na rys.8.

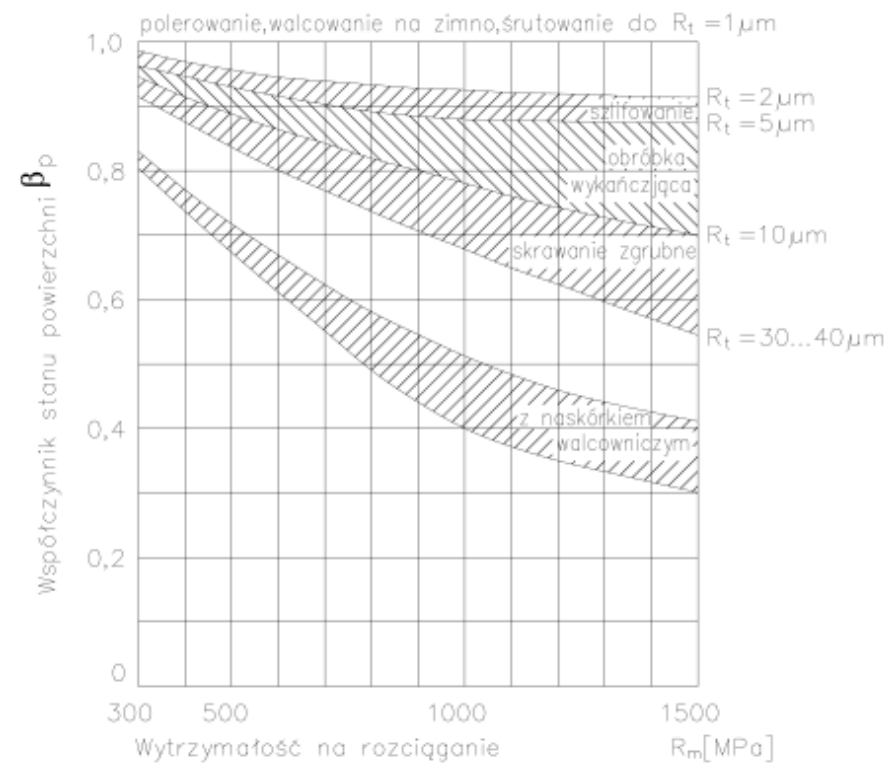

Rys.8. Zależność współczynnika $\beta_{\mathrm{P}}$ (współczynnik stanu powierzchni), charakteryzującego wrażliwość na działanie karbu od parametru $R_{\mathrm{m}}$ wg [6] 


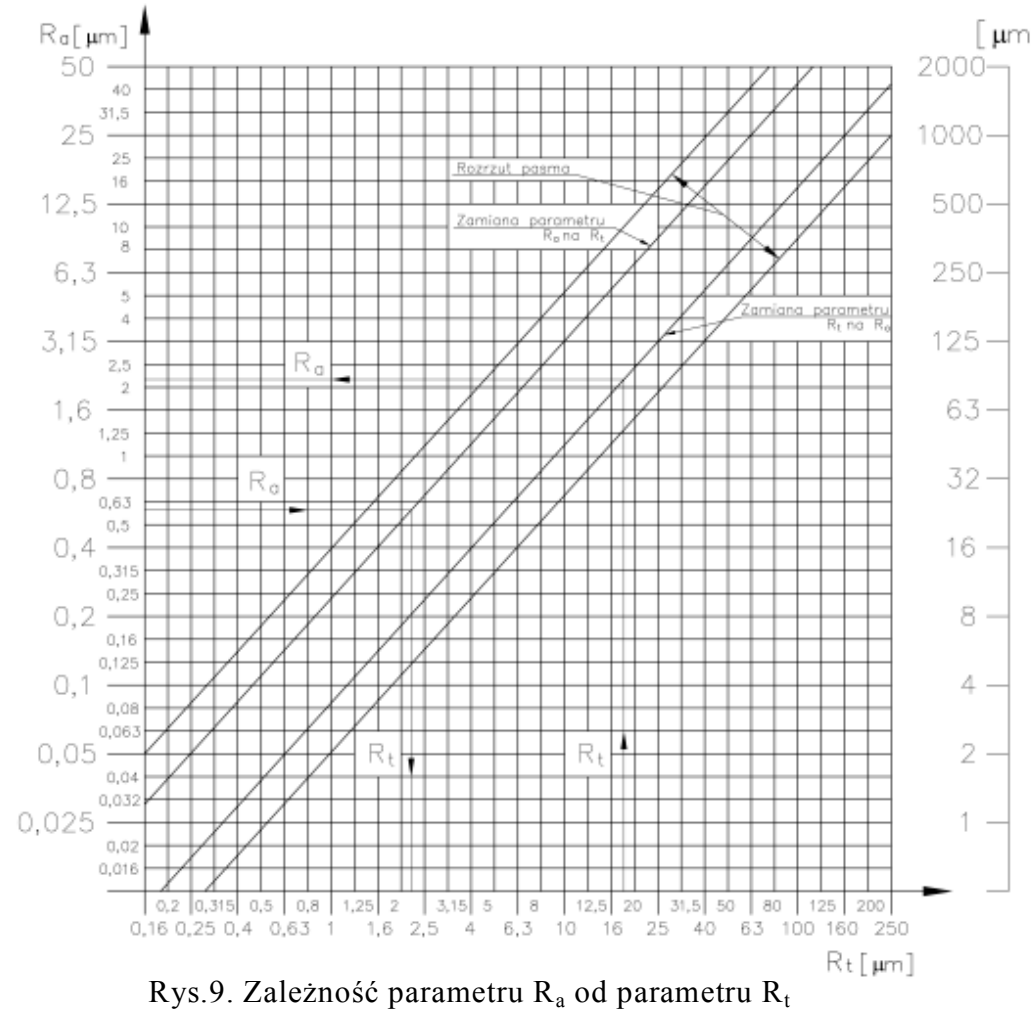

(podpiaść) dla głowic do badań ultradźwiękowych. Zastosowanie metody szczegółowej badań ultradźwiękowych, która wiąże się z koniecznością stłaczania kół, tarcz hamulcowych, kół zębatych oraz pierścieni wewnętrznych łożysk osiowych jest pracochłonne i wiąże się z ryzykiem uszkodzenia powierzchni osadczych. Nie mniej jest to konieczne ze względu na fakt, że dostępne są wszystkie powierzchnie osi zestawu kołowego. Badania ultradźwiękowe należy przeprowadzić zgodnie z instrukcją, która jest uzgodniona pomiędzy klientem a zamawiającym. W takim przypadku wskazane byłoby opracowanie karty badań ultradźwiękowych, która zawierałaby następujące dane:

$>$ datę przeprowadzenia badań ultradźwiękowych

$>\mathrm{nr}$ osi kontrolowanego zestawu kołowego

$>$ rodzaj badań ultradźwiękowych (badania uproszczone, częściowo uproszczone lub szczegółowe)

Współczynnik $\beta_{\mathrm{P}}\left(\mathrm{K}_{\mathrm{F}}\right)$, przedstawiony na wykresie jest wstawiany do wzoru na pojedynczą amplitudę i określa wytrzymałość zmęczeniową w sposób następujący:

$$
\sigma_{A 2}=\sigma_{A} \cdot K_{F} \cdot K_{O}
$$

$\sigma_{\mathrm{A} 2}$ - amplituda, określająca wytrzymałość zmęczeniowa próbki z karbem

$\sigma_{\mathrm{A}}$ - amplituda, określająca wytrzymałość zmęczeniową próbki gładkiej bez zmiany kształtu

$\mathrm{K}_{\mathrm{F}}$ - współczynnik stanu powierzchni

$\mathrm{K}_{\mathrm{O}}$ - współczynnik wielkości próbki (zależności od średnicy próbki).

Zależność parametru $R_{t}$ od parametru $R_{a}$ jest przedstawiona na rys.9.

W przypadku kontroli średnic czopów, przedpiaść oraz podpiaść (osadzeń) należy zwrócić uwage na ich wartość. Jeśli wartość wymiarów średnic osiagnęła już wymiar kresowy nie można już osi dalej kwalifikować do eksploatacji. Przeprowadzone pomiary należy udokumentować w karcie pomiarowej.

\subsubsection{KONTROLA ULTRADŹWIĘKOWA}

Kontrolę wad wewnętrznych w osi należy przeprowadzić wg metody szczegółowej metodą ultradźwiękową UT. Badania należy przeprowadzić w oparciu o instrukcję uzgodnioną $\mathrm{z}$ przedstawicielem użytkownika-klienta. Personel prowadzący badania powinien być kwalifikowany i certyfikowany zgodnie z normą europejską EN 473 [7] lub karta UIC 960 [25]. Badania szczegółowe wymagają dostępności wszystkich badanych fragmentów osi zestawu kołowego. W takim przypadku należy stłoczyć koła, tarcze hamulcowe lub koła zębate, aby był dostęp do osadzeń
$>$ imię i nazwisko operatora, przeprowadzającego badania

$>$ rodzaj użytych głowic oraz miejsce ich przyłożenia

$>$ zmierzone osłabienie echa

$>$ rezultat badań ultradźwiękowych tzn. pozytywny lub negatywny

$>$ ewentualny opis wykrytej wady i jej lokalizacje

$>$ ostatnią datę przeprowadzenia wzorcowania aparatury.

\subsubsection{KONTROLA MAGNETOSKOPOWA}

Kontrolę wad zewnętrznych w osi należy przeprowadzić metodą magnetoskopową MT wg instrukcji uzgodnionej z przedstawicielem użytkownikaklienta. Jako kryteria oceny dopuszczalnych wad zewnętrznych tzn.:

$\Rightarrow$ maksymalną długość pojedynczych wad

$\Rightarrow$ maksymalną długość całkowitą wszystkich wad.

Dla poszczególnych stref (zakresów) osi należy przyjąć dla kategorii 2 wg tabeli 8 p.3.7.2.2 PN-EN 13261:2011+A1 [11]. Kategoria 2 osi jest przeznaczona dla pojazdów, przystosowanych do prędkości mniejszej od $200 \mathrm{~km} / \mathrm{h}$. na powierzchniach osi dla badań magnetoskopowych są podane w tabeli 5 .
Kryteria dotyczące dopuszczalnych wad zewnętrznych 


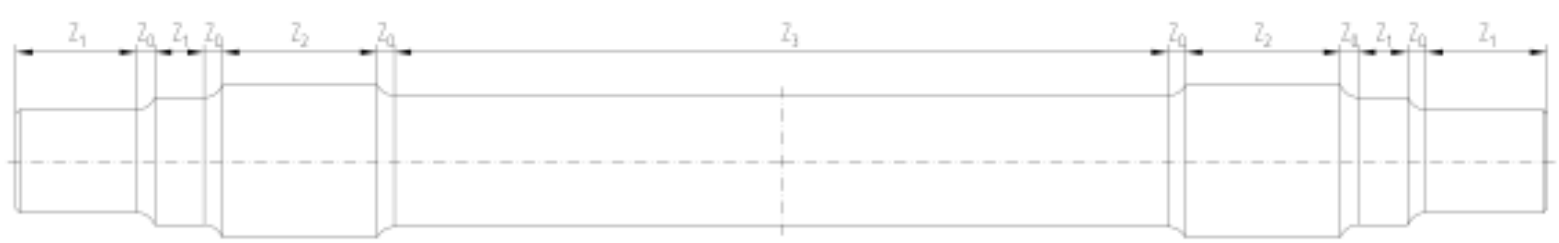

Rys.10. Podział na strefy osi zestawu kołowego w związku z kryteriami badań magnetoskopowych wg tabeli 3

Kryteria dotyczące dopuszczalnych wad zewnętrznych na powierzchniach osi dla badań magnetoskopowych

Tabela 5

\begin{tabular}{|c|c|c|c|}
\hline L.p. & Strefa & \multicolumn{2}{|c|}{ Kategoria 2 } \\
\hline & & $\begin{array}{c}\text { Maksymalna } \\
\text { długość poje- } \\
\text { dynczych wad }\end{array}$ & $\begin{array}{c}\text { Maksymalna dłu- } \\
\text { gość całkowita } \\
\text { wszystkich wad }\end{array}$ \\
\hline 1 & $\mathrm{z}_{0}$ & 0 & 0 \\
\hline 2 & $\mathrm{z}_{1}$ & $\leq 6 \mathrm{~mm}$ & $\leq 6 \mathrm{~mm}$ \\
\hline 3 & $\mathrm{z}_{2}$ & $\leq 6 \mathrm{~mm}$ & $\leq 6 \mathrm{~mm}$ \\
\hline 4 & $\mathrm{z}_{3}$ & $\leq 10 \mathrm{~mm}$ & $\leq 30 \mathrm{~mm}$ \\
\hline
\end{tabular}

1) przez wady pojedyncze rozumie się takie, których wzajemna odległość wynosi minimum $10 \mathrm{~mm}$

Poszczególne strefy osi $z_{0}, z_{1}, z_{2}$ i $z_{3}$ są podane na rys.10.

Każdą oś po badaniach magnetoskopowych należy koniecznie poddać procesowi rozmagnesowania. Magnetyzm szczątkowy (po procesie rozmagnetyzowania) nie może przekraczać $320 \mathrm{~A} / \mathrm{m}=4 \mathrm{Gs}=0,4 \mathrm{mT}$.

\subsubsection{PRZYGOTOWANIE OSI DO PONOWNEJ EKSPLOATACJI}

Oś powinna być zabezpieczona powłoką malarską antykorozyjną klasy 2 zgodnie $\mathrm{z}$ tabelą 11 p.3.9.1.1 wg PN-EN 13261+A1:2011 [11] w strefach poza osadzeniami.

Zabezpieczenie antykorozyjne traktuje się tutaj jako istotny czynnik zapewnienia wytrzymałości zmęczeniowej zgodnie z p.7.2 normy PN-EN 13103:2009 [8]. Ustalone granice zmęczenia dla osi zestawów kołowych obowiązują wtedy, gdy ,warunki eksploatacji zapewniaja prawidlowe zabezpieczenie przed korozja przez caly czas użtkowania osi. Jeżeli istniejq watpliwości, że zabezpieczenie przed korozja nie będzie skuteczne, to graniczne naprężenia powinny być podzielone przez współczynnik uzgodniony przez projektanta $i$ Zamawiajacego, uwzględniajacy przepisy utrzymania stosowane przez uzytkownika." Z takiego zapisu można wnioskować, że metodykę wyznaczania sił oraz naprężeń w poszczególnych strefach osi można uznać za miarodajną, jeśli producent gwarantuje prawidłowe zabezpieczenie antykorozyjne powierzchni znajdujących się poza osadzeniami osi. Zabezpieczenie antykorozyjne, które jest właściwie dobrane, powinno chronić powierzchnię osi przed uszkodzeniami mechanicznymi, typu uderzenia thucznia na- wierzchni kolejowej, odprysków metalicznych pochodzących z procesów zużycia. Problematyka właściwego doboru powłoki malarskiej jako zabezpieczenia antykorozyjnego została szczegółowo omówiona w opracowaniu [3]. Powłoka klasy 2 powinna posiadać odpowiednią grubość, którą należy mierzyć po jej wykonaniu (najlepiej za pomoca grubościomierza elektronicznego) oraz posiadać odpowiednią przyczepność, odporność na odrywanie, na działanie wody morskiej, mediów korozyjnych jak również na działanie cyklicznych obciążeń mechanicznych. Pomiar tych właściwości powinien być przeprowadzony na zgodność z PN-EN 13261+A1:2011 [11]. Zaleca się, aby w przypadku nawisów piast kół jezdnych, kół zębatych i tarcz hamulcowych dokonywać zabezpieczenia „ukrytych zagłębień” przed korozją za pomocą środka antykorozyjnego LOCTITE 5699. Zagadnienie to jest opisane szerzej w opracowaniu [3].

\section{ALGORYTM KWALIFIKACJI OSI}

Algorytm kwalifikacji osi „staroużytecznych” jest przedstawiony na rys. 11 .

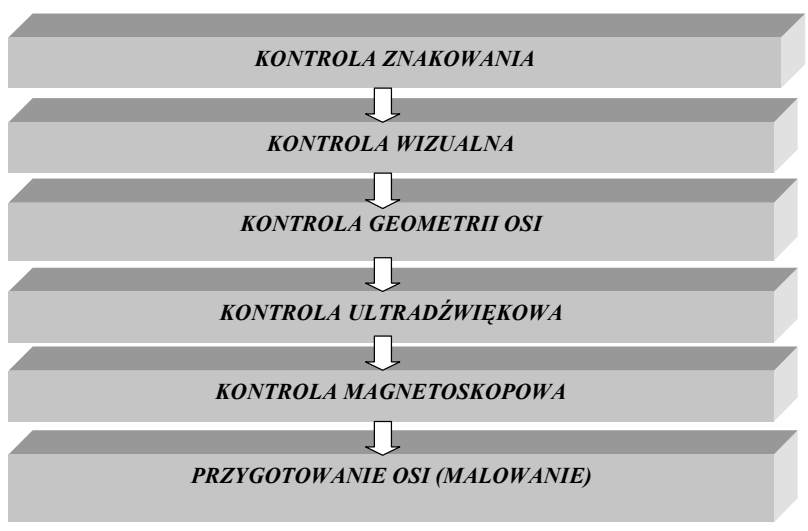

Rys.11. Algorytm kwalifikacji osi „staroużytecznych”

Schemat przedstawiony na rys. 11 jest uproszczony $\mathrm{i}$ ogranicza się do zasadniczych czynności, które należy wykonać przy kwalifikowaniu osi „staroużytecznych”. Warunkiem rozpoczęcia kolejnego etapu jest pozytywne zakończenie poprzedzającego. Szczególną uwagę należy zwrócić na stronę diagnostyczną całego zagadnienia. Zwłaszcza na pozytywny wynik badań diagnostycznych tzn. badań wizualnych, badań ultradźwiękowych oraz badań magnetoskopowych. Jak wykazuje dotychczasowa praktyka eksploatacyjna na bezpieczeństwo jazdy w aspekcie kwalifikowanych osi 
zestawów kołowych mają elementy bezpośrednio współpracujące jak np. koła czy łożyska. Okazuje się, że jedną z przyczyn pęknięć osi jest zatarcie łożyska. W przypadku utraty zdolności obrotowej łożyska, spowodowanej np. zbyt małymi luzami promieniowymi łożyska, złą jakością smaru, jego zanieczyszczeniami opiłkami metalicznymi uszkadzających się elementów jak np. wałeczków lub koszyka następuje najczęściej poluzowanie pierścieni wewnętrznych łożyska, które mając dużo większą twardość powodują „skrawanie powierzchni czopa" i w konsekwencji utratę nośności tej części osi (pękniecie czopa). Procesowi temu towarzyszy bardzo duża emisja ciepła, powodując częściowe lub całkowite „stopienie” smaru. Procesy zatarcia łożysk odbywają się w krótkich okresach czasu i często urządzenia do wykrywania przegrzanych łożysk, rozmieszczone wzdłuż toru nie mogą ich wykryć. Na aspekt ten należy zwrócić uwagę, zwłaszcza że w większości zarządów kolejowych panuje tendencja wykorzystywania łożysk posiadających wiek 40 lat i powyżej, gdzie ryzyko powstania tego typu zjawisk jest znacznie większe.

W przypadku zastosowania zestawów kołowych $\mathrm{z}$ osiami „staroużytecznymi” należy przestrzegać wszystkich wymagań związanych w wymaganiami dotyczącymi kół, które są zawarte w PN-EN 13262+A1:2009 [12], PN-EN 13715:2008 [13], PNEN 13979-1:2007 [14], karty UIC 510-5 [21] oraz wymagań montażu kół, przedstawionych w PN-EN 13260:2009 [10] oraz karty UIC 813 [24].

\section{WNIOSKI}

Wprowadzenie do eksploatacji osi ,staroużytecznych" ma poważny wymiar ekonomiczny, rzutujący na pozycję rynkową transportu szynowego. Warunkiem powodzenia takiego przedsięwzięcia jest ścisłe przestrzeganie zaproponowanych procedur. Bardzo ważną rolę odgrywa tutaj pozytywny wynik badań diagnostycznych tzn. badań wizualnych, badań ultradźwiękowych oraz badań magnetoskopowych. Osie takie po przejściu wszystkich wymaganych procedur mogą być uznane jako spełniające wymagania dla bezpiecznej eksploatacji komercyjnej. Należy zwrócić szczególną uwagę na to, że oś jest powiązana bezpośrednio $\mathrm{z}$ innymi elementami układu biegowego, do których można zaliczyć koła, maźnice wraz z łożyskami oraz tarcze hamulcowe lub koła zębate. Niewłaściwy montaż lub dysfunkcja któregoś $\mathrm{z}$ wymienionych elementów może prowadzić do ograniczenia żywotności samej osi. Określenie granicznego wieku nie ma większego sensu technicznego. Jak pokazuje praktyka eksploatacyjna nawet wiek 40 lat jest przekraczany i nie powoduje to wypadków kolejowych. Z przeprowadzonych ekspertyz, dotyczących przyczyn uszkodzeń osi zestawów kołowych wiek osi zestawów kołowych nigdy nie był podnoszony jako przyczyna wypadku lub katastrofy kolejowej. Wiek uszkodzo- nych zestawów kołowych był różny, a miejsca uszkodzeń oraz przyczyny ich powstawania bardzo różne. Wątpliwości budził przede wszystkim stan zestawów kołowych (np. zaawansowana korozja na przedpiaściu lub w części środkowej osi), stwierdzano uszkodzenia mechaniczne, jako zarodki pęknięć zmęczeniowych oraz utratę funkcji obrotowej łożysk. Z przeprowadzonych ekspertyz wynika jednak jasno, że właściwa droga do bezpiecznej eksploatacji jest związana $\mathrm{z}$ rozwojem i prawidłowym stosowaniem metod diagnostycznych. Kontrola ta powinna być udokumentowana, tak aby można było w krótkim czasie wprowadzić „monitoring” eksploatowanych osi zestawów kołowych, który mógłby prowadzić użytkownik taboru. Właściwa kwalifikacja osi i prawidłowy sposób zabudowy gwarantuje bezpieczna eksploatację. Niniejsze opracowanie zawiera ogólne wytyczne dotyczące sposobu kwalifikacji osi „staroużytecznych”. Na podstawie tych wytycznych można opracować dokumenty, posiadające charakter szczegółowych instrukcji kwalifikacji. Dokumenty takie powinien opracować użytkownik taboru pojazdów szynowych i przedłożyć je do zatwierdzenia jednostce certyfikującej. Taki dokument może mieć dopiero charakter całkowicie utylitarny.

\section{LITERATURA}

[1] Sobaś M.: Diagnostyka osi zestawów kołowych układów biegowych pojazdów trakcyjnych i tocznych. Pojazdy Szynowe nr 4/2010

[2] Sobaś M.: Kryteria obiektywnej oceny prognozowanych stanów osi zestawów osi zestawów kołowych pojazdów trakcyjnych. Pojazdy Szynowe nr 1/2011.

[3] Sobaś M.: Zabiegi technologiczne zwiększajace żywotność osi zestawów kołowych. Pojazdy Szynowe $n r$ $4 / 2011$

[4] Sobaś M.: Przedsięwzięcia zwiększajace prognozowana żywotność osi zestawów kołowych w skali unii europejskiej. Pojazdy Szynowe nr 1/2012.

[5] Stasiak L.: Doświadczalna determinacja charakterystyk wytrzymałości zmęczeniowej osi zestawów kołowych pojazdów szynowych. Rozprawy Nr 173. Poznań 1986.

[6] Tauscher H.: Dauerfestigkeit von Stahl und Gusseisen. 4-te neuaufbearbeitete Auflage, Leipzig 1982.

[7] EN 473: Kwalifikacja i certyfikacja personelu do badań nieniszczacych. Ogólne zasady.

[8] PN-EN 13103:2011: Kolejnictwo. Zestawy kołowe $i$ wózki. Osie zestawów kołowych tocznych. Zasady konstrukcji.

[9] PN-EN 13104:2011: Kolejnictwo. Zestawy kołowe $i$ wózki. Osie zestawów kołowych napędnych. Zasady konstrukcji.

[10] PN-EN 13260:2009: Kolejnictwo. Zestawy kołowe $i$ wózki. Zestawy kołowe. Wymagania dotyczace wyrobu.

[11] PN-EN 13261+A1:2011: Kolejnictwo. Zestawy kołowe $i$ wózki. Osie. Wymagania dotyczqce wyrobu.

[12] PN-EN 13262+A1:2009: Kolejnictwo. Zestawy kołowe $i$ wózki. Koła. Wymagania dotyczqce wyrobu.

[13] PN-EN 13715:2008: Kolejnictwo. Zestawy kołowe $i$ wózki. Koła. Zewnętrzne zarysy wieńców kót. 
[14] PN-EN 13979-1:2007: Kolejnictwo. Zestawy kołowe $i$ wózki. Kola monoblokowe. Procedura dopuszczenia. Część 1: Koła kute i walcowane.

[15] PN-EN 15313: Kolejnictwo. Zestawy kołowe znajdujace się $w$ eksploatacji. Utrzymanie zestawów kołowych $w$ stanie zabudowanym lub po demonta$\dot{z} u$.

[16] PN-64/H-84027: Stal dla kolejnictwa. Osie zestawów kołowych. Gatunki.

[17] PN-84/H-84027/03: Stal dla kolejnictwa. Osie zestawów kołowych do pojazdów szynowych. Gatunki.

[18] PN-91/H-84027/03: Stal dla kolejnictwa. Osie zestawów kołowych do pojazdów szynowych. Gatunki.

[19] PN-92/K-91048: Wagony towarowe. Osie zestawów kołowych.

[20] Karta UIC 510-1: Wagony towarowe. Uktad biegowy-Normalizacja. 9-te wydanie z 1.01. 1978. 14ście zmian od 1.01.1980 do 1.01.1997.

[21] Karta UIC 510-5: Dopuszczenie kót monoblokowych-zastosowany dokument dla EN 139791.2-gie wydanie z maja 2007 roku.
[22] Karta UIC 515-3: Pojazdy kolejowe. Wózki-układy biegowe. Metoda obliczeń osi zestawów kołowych. 1-sze wydanie z 1.07.1994

[23] Karta UIC 811-1: Warunki techniczne na dostawe osi zestawów kołowych dla nowobudowanych pojazdów trakcyjnych $i$ wagonów. 4-te wydanie $z$ 1.01.1987 (karta unieważniona 2005 rok)

[24] Karta UIC 813: Warunki techniczne na dostawe zestawów kołowych dla taboru trakcyjnego $i$ wagonów. 2-gie wydanie z grudnia 2003.

[25] Karta UIC 960: Kwalifikacja i certyfikacja personelu odpowiedzialnego za prowadzenie badań nieniszczacych elementów zespołów pojazdów szynowych $w$ procesie ich utrzymania.2gie wydanie z grudnia 2001.

[26] Raport ORE/ERRI B12/Rp.14/D: Frage B12. Vereinheitlichung der Güterwagen. StandardDrehgestell. Bericht Nr.14. Utrecht, listopad 1967.

[27] Raport ORE/ERRI B136/Rp.11/D: Zestawy kołowe $z$ nasadzanymi tożyskami tocznymi. Konstrukcja, utrzymanie $i$ standaryzacja. Obliczenie osi zestawów kołowych dla wagonów towarowych $i$ osobowych. Utrecht, kwiecień 1979. 